6. Lesechko, M.D. \& Rudnytska, R.M. (2004). Stratehichne planuvannia: navchalnyi posibnyk [Strategic Planning: A Tutorial]. Lviv, 76 p. [in Ukrainian].

7. Natroshvili, S.H. (2015). Stratehichne upravlinnia vyshchym navchalnym zakladom: teoriia, metodolohiia, praktyka: monohrafiia [Strategic Management of Higher Education: Theory, Methodology, Practice: Monograph]. Kyiv, 326 p. [in Ukrainian].

8. Riding, K. (2005). Strategicheskoe biznesplanirovanie: Dinamicheskaya sistema povysheniya effektivnosti i obespecheniya konkurentnogo preimushchestva [Strategic business planning: A dynamic system to increase efficiency and provide a competitive advantage]. (Ed.). I.A. Voytyuk. Dnepropetrovsk, 384 p. [in Russian].

9. Svystovych, M.B. Sutnist i osnovni poniattia stratehichnoho planuvannia [The essence and basic concepts of strategic planning]. Available at: http:// academy.gov.ua/ej/ej18/PDF/06.pdf [in Ukrainian].

10. Ackoff, R. (1970).Concept of Corporate Planning. New York:Wiley, p.1. [in English].

11. Grang-Chol CHANG Strategic Planning in Education: Some Concept and Methods Vendredi 4 juillet 2008. Available at: http://www.iiep.unesco.org/. [in English].

Стаття надійшла до редакції 27.09.2019

DOI:

Світлана Шумовецька, кандидат педагогічних наук, доцент кафедри педагогіки та соиіально-економічних дисииплін Національної академії Державної прикордонної служби імені Б. Хмельницького

\title{
ПЕДАГОГІЧНІ УМОВИ ФОРМУВАННЯ ПРОФЕСІЙНОЇ КУЛЬТУРИ МАЙБУТНІХ ОФІЦЕРІВ-ПРИКОРДОННИКІВ: ВИКОРИСТАННЯ ПОТЕНЦІАЛУ ПРОБЛЕМНИХ МЕТОДІВ
}

У статті розкрито значення проблемних методів для формування професійної культури майбутніх офічерів-прикордонників. Наведено приклади використання проблемних методів під час викладання навчальної дисиипліни "Історія війн, конфліктів та охорони державного кордону", насамперед ситуації конфлікту, проблемні завдання, щзо потребують з'ясування причин та наслідків подій, узагальнення, систематизачії чи спростування. Доведено, що використання проблемних методів навчання стимулюватиме розвиток пізнавальної активності майбутніх офіџерів-прикордонників, допоможе вчити їх бачити проблеми та визначати шляхи їх розв 'язання, дозволить формувати їх характер й розуміння моральної відповідальності, необхідності долати труднощі.

Ключові слова: професійна культура; офіцер-прикордонник; педагогічні умови; курсанти; проблемні методи; проблемні ситуаиіiі.

Лim. 8.

Svitlana Shumovetska, Ph.D.(Pedagogy), Associate Professor of the Pedagogy and SocioEconomic Sciences Department National Academy of the State Border Service named after Bohdan Khmelnytskiy

\section{PEDAGOGICALCONDITIONS OF FORMATION THE PROFESSIONAL CULTURE OF FUTURE FRONTIER OFFICERS: USE OF THE POTENTIAL OF PROBLEM METHODS}

The advantages and importance of problematic methods for formation the professional culture of future frontier officers have been revealed in the article. Problematic methods are evidence of non-directive pedagogy, that is, one that prioritizes the active role of the individual in the acquisition of knowledge and the acquisition of professional skills. It has been suggested to present problem situations in the form of various professional tasks, consecutive problem situations, which must necessarily contain some contradiction, which requires their analysis, formulation of problems and their solving. The methodological value of the problematic method is that the cadets master their professional knowledge more intensively, solve problems, rather than listen to the teacher passively. Through problem-based training, teachers can create the necessary conditions for independent decision-making, comparison of different behavioral options, change of orientation in training from gaining to acquisition of knowledge, from passive consumption to active analysis. Advantages of problem-based methods of training are high level of independence of cadets, intensification of their mental activity.

Examples of the use of problematic methods in teaching the subject of History of Wars, Conflicts and State 


\section{ПЕДАГОГІЧНІ УМОВИ ФОРМУВАННЯ ПРОФЕСІЙНОӤ КУЛЬТУРИ МАЙБУТНІХОФІЦЕРІВ- ПРИКОРДОННИКІВ: ВИКОРИСТАННЯПОТЕНЦІАЛУ ПРОБЛЕМНИХМЕТОДІВ}

Border Protection have been given, first of all conflict situations and problematic tasks, which need to clarify the causes and consequences of events occurring in the Ukrainian military, as well as generalization, systematization or refutation of certain historical myths related to the colonial history of Ukraine. It has been proved that the use of problem-based methods of education allows to form personal qualities of future defenders of the border, such as independence, perseverance, purposefulness, etc., which is necessary for shaping their ability to make independent decisions, ability to apply theoretical provisions for successful overcoming problems and difficulties of daily life.

Keywords: professional culture; a frontier officer; pedagogical conditions; cadets; problem-based methods; problem-based situations.

П остановка проблеми в загальному вигляді. Значення прикордонної служби має загальнодержавний характер: прикордонники покликані забезпечувати прикордонну безпеку як важливу складову національної безпеки, тобто захищати національні інтереси у прикордонній сфері. Ця професія потребує людей національно свідомих, відданих Батьківщині, готових до наполегливої та напруженої праці. 3 огляду на необхідність покращення рівня професійної підготовки майбутніх захисників кордону, підвищення рівня їх готовності до виконання складних завдань професійної діяльності формування професійної культури майбутніх офіцерів-прикордонників $\epsilon$ важливим завданням педагогіки вищої школи.

Аналіз останніх досліджень і публікацій. Проблема формування професійної культури майбутніх офіцерів-прикордонників $є$ масштабною та багатоаспектною. Значна група досліджень стосується історичних аспектів становлення професійної культури козацтва як представників першої професійної прикордонної сторожі України (В. Горобець, Ю. Мицик, С. Плохій, Т. Чухліб, Ю. Фігурний та ін.). Ще одна група наукових напрацювань - це дослідження проблематики професійної культури офіцерів Збройних сил України та загалом правоохоронних органів (В. Зелений, О. Кравченко, І. Михайліченко, С. Сливка та ін.). Важливе значення мають також дослідження окремих аспектів професійної культури офіцерів-прикордонників, насамперед щодо розвитку їх професійних якостей, готовності до педагогічної та управлінської діяльності (В. Балашов, Ю. Дем'янюк, Д. Іщенко, О. Сафін та ін.). Безпосередньо проблематика професійної культури $є$ предметом уваги I. Балицького, С. Білявця, I. Почекаліна, Т. Щеголєвої, В. Царенка, В. Хоми, В. Мірошніченко та ін. Проте незважаючи на це особливості формування професійної культури майбутніх офіцерівприкордонників з урахуванням нових викликів прикордонній безпеці на сьогодні не досліджено.

Формулювання мети статті. Метою статті $\epsilon$ розкриття значення проблемних методів для формування професійної культури майбутніх офіцерів-прикордонників.
Виклад основного матеріалу. Необхідність використання потенціалу проблемних методів навчання для формування професійної культури майбутніх офіцерів-прикордонників обумовлена суттєвими перевагами цих методів. В. Сухомлинський щодо цього підкреслював, що “як леміш плуга очищається від іржі й стає дзеркально чистим, коли плуг щодня оре землю, так і душа людини світлішає, коли вона в труді долає труднощі, мужньо зустрічає невдачі, не тішачись успіхами і завжди прагнучи до того, чого не досягнуто. Труднощі, перешкоди, знегоди пробний камінь переконань. Труднощі, необхідні для морального загартування, - у самій природі творчої праці" [7, 126].

В. Сухомлинський звертав увагу на важливість труднощів: "Радість праці - це передусім радість подолання труднощів, горде усвідомлення й переживання того, що ми, напружуючи фізичні й духовні сили, піднялись на вершину... Радість праці - в гордому поступі до вершини, в досягненні перемоги..." [7, 496]. Педагог підкреслював доцільність і необхідність проблемного навчання, стверджуючи, що не треба боятись “затьмарити сонце золотого дитинства тим, що дитині буде важко, що вона, напружуючи свої зусилля, зробить більше, ніж, здавалося б, дозволяють їй маленькі сили. В отому “більше, ніж здавалося б", можливо, й полягає крок по тій нелегкій стежці до вершини" [7, 496 - 497].

Проблемні методи навчання, на думку І. Беха, мають великі можливості щодо творчого освоєння особистістю моральних цінностей. Педагог називає проблемні методи свідченням недирективної педагогіки, тобто тієї, яка надає пріоритет активній ролі особистості в засвоєнні знань і моральних норм. Проблемні методи, як зазначає І. Бех, обумовлюють ситуацію, коли у суб'єктів навчання виникає природна необхідність приймати рішення самим, що розвиватиме внутрішню потребу моральної поведінки без примусу ззовні. Ще однією перевагою проблемних методів учений називає сприяння здатності розмірковувати, що спонукатиме молодь до самоаналізу, до тієї внутрішньої роботи, що закріплюватиме виховні впливи, буде основою 


\section{ПЕДАГОГІЧНІ УМОВИ ФОРМУВАННЯ ПРОФЕСІЙНОӤ КУЛЬТУРИ МАЙБУТНІХ ОФІЦЕРІВ- ПРИКОРДОННИКІВ: ВИКОРИСТАННЯ ПОТЕНЦІАЛУ ПРОБЛЕМНИХМЕТОДІВ}

для моральної поведінки у різних життєвих ситуаціях [2, 3 - 4].

Викладати гуманітарні дисципліни, вважає I. Павленко, не можливо без орієнтування на проблемний характер. Це обумовлено тим, що на заняттях $з$ гуманітарних дисциплін майбутні фахівці повинні здійснювати активний аналіз, а не пасивно “споживати” знання. Проблемні методи допомагають прищеплювати їм навички критичного ставлення до навчального матеріалу, формувати здатність до самостійних висновків, уміння застосовувати теоретичні положення до повсякденного життя, що необхідно для успішного подолання ними проблем, труднощів майбутнього професійного життя [6, 44]. I. Павленко зазначає, що саме гуманітарні предмети дозволяють ураховувати колізійність матеріалу, дають можливість викладати й захищати різні точки зору, моделювати взаємини між представниками різних соціальних груп чи професій [6, 44 - 45].

Проблемні ситуації учені пропонують формулювати у вигляді різноманітних професійних завдань, що обов'язково мають містити певну суперечність. М. Фіцула зазначає, що ознакою проблемного навчання є створення системи послідовних проблемних ситуацій, що потребує їх аналізу, формулювання проблем і розв'язання [8, 178]. М. Фіцула вважає, що про проблемну ситуацію може свідчити ситуація несподіваності, ситуація конфлікту, ситуація передбачення, ситуація спростування, ситуація невідповідності, ситуація невизначеності $[8,180]$. Проблемне навчання, зазначає учений, допомагає змінити мотивацію пізнавальної діяльності: провідними стають мотиви пізнавально-спонукальні (інтелектуальні) [8, 178].

У Національній академії Державної прикордонної служби ім. Богдана Хмельницького під час вивчення з навчальної дисципліни “Історія війн, конфліктів та охорони державного кордону” викладачі пропонують курсантам для аналізу ситуацію конфлікту на кшталт: “За Катерини II велику увагу Російська імперія приділяла топоніміці та перейменуванню населених пунктів. Так, наприклад, одна 3 перших битв, у якій українці дали відсіч монгольським завойовникам, відбулась біля річки Синюхи. Це поле битви увійшло в історію як Бранне поле. За Катерини його було перейменовано у Бараняче поле" [3, 278]. Для вирішення цього завдання курсанти повинні дати відповідь на питання, чим це було обумовлено та які мало наслідки. Вони повинні 3'ясувати, що імперська традиція обмежувала право українців на свою історію, українців не прийнято було зображувати як мужніх воїнів.
Перейменовуючи міста і села, імперія стирала пам'ять колонізованих про їх історію, про їх силу чи мілітарну потугу, перетворюючи їх із народу воїнів на народ баранів.

Доцільно також пропонувати курсантам проблемні завдання, що потребують 3'ясування причин та наслідків подій, узагальнення, систематизації чи спростування. До прикладу, важливими є слова О. Однороженка про те, що “відповідно до “звичайної схеми” української історії, українці - це упосліджена бездержавна нація, позбавлена власної еліти, миролюбна хліборобська маса холопів без військового хисту і прагнення до експансії, перманентно кривджена всіма своїми сусідами" [5]. Спростовуючи твердження про слабку мілітарну міць українців, курсанти повинні відповісти на питання про те, як такий “безхребетний” народ зміг не лише втриматися на цій вузловій у геополітичному сенсі території, а й від сторіччя до сторіччя поширював власний життєвий простір за рахунок “войовничих та агресивних" сусідів? Чому ми досі велика нація з усіма шансами на великодержавний успіх, а наші історичні вороги зі степового кордону або канули в Лету, або перетворилися на маргінальні етнографічні релікти? Що забезпечило нам цей історичний успіх - невже миролюбність і нездатність до державотворення й мілітарної потуги?” [5]. Курсанти на прикладах з історії України та українського війська $[5,52]$ повинні довести, що діяння українців (Gesta Ruthenorum) - це безперервні військові походи, захист, завоювання і нищення ворогів, тому предки українців були визначними воїнами, інакше вони не змогли б зберегти Україну. Розв'язуючи подібні завдання, курсанти робили висновок про те, що в Україні довгий час переважала не українська, а радянська мілітарна історія, не було україноцентричного погляду на історію перемог i поразок українського війська.

Доцільно також запропонувати курсантам проаналізувати висловлювання іноземних інструкторів щодо дій українського війська. Йдеться про слова Цві Аріелі, інструктора 1-ї бригади швидкого реагування Національної гвардії України, яка формується за стандартами НАТО, щодо того, що в українській армії $є$ дуже багато від радянського, що не дозволяє їй змінитись якісно [1]. Це ж підтверджує і британський військовий експерт НАТО Г. Грант, стверджуючи, що головною проблемою нинішніх Збройних сил України $є$ те, що вони все ще фундаментально розбудовуються та підтримується на засадах радянської армії [4]. Курсанти повинні визначити, в чому виявляється радянська 


\section{ПЕДАГОГІЧНІ УМОВИ ФОРМУВАННЯ ПРОФЕСІЙНОӤ КУЛЬТУРИ МАЙБУТНІХ ОФПЦЕРІВ- ПРИКОРДОННИКІВ: ВИКОРИСТАННЯПОТЕНЦІАЛУ ПРОБЛЕМНИХ МЕТОДІВ}

спадщина в українському війську, на чому вона грунтується. Важливо, щоб курсанти, як і Г. Грант, зробили висновок, що вирішальним фактором виграшу у військовому конфлікті є дух вільної людини, тобто зміна застарілої філософії, оскільки “невелика радянська армія не може виграти війну проти великої радянської арміі” [4].

У зазначених випадках методична цінність проблемних методів полягає у тому, що курсанти більш інтенсивно опановуватимуть професійні знання, вирішуватимуть проблеми, а не пасивно прослуховуватимуть викладача. За допомогою проблемного навчання викладачі можуть створити необхідні умови для самостійного прийняття рішення, порівняння різних поведінкових варіантів, зміни орієнтації в навчанні від отримування до здобування знань, від пасивного “споживання” до активного аналізу, формувати такі особистісні якості майбутніх захисників кордону, як самостійність, наполегливість, цілеспрямованість та ін., що необхідно для формування здатності до самостійних висновків, уміння застосовувати теоретичні положення у повсякденному житті, для успішного подолання проблем і труднощів майбутнього професійного життя.

Висновки. Використання проблемних методів навчання стимулюватиме розвиток пізнавальної активності майбутніх офіцерівприкордонників, допоможе вчити їх бачити проблему та визначати шляхи іiі розв'язання, дозволить формувати їх характер й розуміння моральної відповідальності, необхідності долати труднощі. Перевагами проблемних методів навчання є високий рівень самостійності курсантів, інтенсифікація їх розумової діяльності.

Перспективи подальших розвідок у зазначеному напрямі. Важливим напрямом подальших досліджень $є$ визначення значення дослідницьких методів для формування професійної культури майбутніх офіцерівприкордонників.

\section{ЛIТЕРАТУРА}

1. Арелі Ц. "Українська армія воює чисельністю, а ізраїльська - професіоналізмом" - інструктор Цві Аріелі. URL: https://znaj.ua/content/ukrayinska-armiyavoyuye-chyselnistyu-izrayilska-profesionalizmominstruktor-cvi-arieli (дата звернення: 29.08.2019).

2. Бех І. Д. Виховання особистості: у 2 кн. Київ: Либідь, 2003. Кн. 1: Особистісно орієнтований підхід: теоретико-технологічні засади. $280 \mathrm{c}$.

3. Білінський В. Україна-Русь: історичне дослідження: у 3-х кн. Кн. 1. Споконвічна земля. Тернопіль: Навчальна книга Богдан, 2015. 384 с.

4. Грант Г. Як українцям побудувати армію, здатну перемогти Путіна. URL: https://censor.net.ua/ua/ resonance/3048160/yak_ukrayintsyam_pobuduvaty _armiyu_zdatnu_peremogty_putina (дата звернення: 10.09.2019).

5. Однороженко О. А. Звичайна схема української історії. Украӥнський тиждень. 2009. № 52 (113). С. 52 54.

6. Павленко I. С. Дидактичний і світоглядний потенціал шкільних предметів гуманітарного циклу. Педагогічна освіта: теорія і практика. Педагогіка. Психологія. 2014. № 21. C. 41-45. URL: http:// nbuv.gov.ua/UJRN/Potip_2014_21_10 (дата звернення: 10.09.2019).

7. Сухомлинський В. О. Проблеми виховання всебічно розвиненої особистості. Вибрані твори: в 5 т. Київ, 1976. Т. 1.654 с.

8. Фіцула М. М. Педагогіка вищої школи: навч. посіб. Київ, 2006. 352 с.

\section{REFERENCES}

1. Areli, Ts. (2017). "Ukrainska armiia voiuie chyselnistiu, a izrailska - profesionalizmom"-instruktor Tsvi Arieli [The "Ukrainian Army Fights the Number and the Israeli Does It with Professionalism" - instructor Tsvi Arieli]. Available at: https://znaj.ua/content/ukrayinskaarmiya-voyuye-chyselnistyu-izrayilska-profesionalizmominstruktor-cvi-arieli (accessed 29 Aug. 2019). [in Ukrainian].

2. Bekh, I. D. (2003). Vykhovannia osobystosti [Personal Education]. U 2 kn. Kn. 1. Osobystisno oriientovanyi pidkhid: teoretyko-tekhnolohichni zasady [Personally Oriented Approach: Theoretical and Technological Principles]. K, 280 p. [in Ukrainian].

3. Bilinskyi, V. (2015). Ukraina-Rus: istorychne doslidzhennia [Ukraine-Rus: a Historical Study]. Ancient Land. Ternopil, 384 p. [in Ukrainian].

4. Hrant, H. (2018). Yak ukraintsiam pobuduvaty armiiu, zdatnu peremohty Putina [How Ukrainians Should Build an Army Capable of Defeating Putin]. Available at: https:/ /censor.net.ua/resonance/3048160/yak_ ukrantsyam pobuduvati_armyu_zdatnu_peremogti_putna (accessed 04 Sept. 2019). [in Ukrainian].

5. Odnorozhenko, O. A. (2009). Zvychaina skhema ukrainskoi istorii [The Usual Scheme of Ukrainian History]. Ukrainskyi tyzhden. No.52 (113). pp. 52-54. [in Ukrainian].

6. Pavlenko, I. S. (2014). Dydaktychnyi i svitohliadnyi potentsial shkilnykh predmetiv humanitarnoho tsyklu [Didactic and Ideological Potential of School Subjects in the Humanitarian Cycle]. Teacher Education: Theory and Practice. Pedagogy. Psychology. No. 21. pp. 41-45. Available at: http://nbuv.gov.ua/UJRN/Potip_2014_21_10 (accessed 04 Sept. 2019). [in Ukrainian].

7. Sukhomlynskyi, V. O. (1976). Problemy vykhovannia vsebichno rozvynenoi osobystosti [Problems of Upbringing of a Comprehensive Personality]. Vybrani tvory: 5 t. Kyiv, Vol. 1. 654 p. [in Ukrainian].

8. Fitsula, M. M. (2006). Pedahohika vyshchoi shkoly [Pedagogy of High School]. Kyiv, 352 p. [in Ukrainian].

Стаття надійшла до редакції 24.09.2019 